\title{
Efficacy of local anaesthetic and steroid combination in prevention of post-herpetic neuralgia: A meta-analysis
}

\author{
Xiaolu Zhang ${ }^{1}$, Zhiwei Wang ${ }^{2}$, Yiyuan Xian ${ }^{3}$
}

\begin{abstract}
Objective: The objective was to provide synthesized evidence on the efficacy of local anaesthetics and steroid injections for prevention and management of PHN, compared to the standard treatment using anti-viral and analgesic medications. The primary outcomes of interest were incidence of PHN and duration of neuralgic pain.

Methods: Comprehensive searches were done systematically through PubMed, Scopus, Cochrane Central Register of Controlled Trials and Google scholar databases. Randomized controlled trials that compared the efficacy of local anaesthetics and steroid injections for preventing and managing PHN were included for this meta-analysis. A comprehensive search was done for papers published until $15^{\text {th }}$ July 2021 .

Results: A total of 10 RCTs were included in the meta-analysis. In the overall pooled analyses, compared to standard care/placebo, those receiving a combination of local anaesthetic and steroid injection had $55 \%$ lower risk of PHN at 3 months from onset of rash (RR $0.45 ; 95 \% \mathrm{Cl}, 0.29 ; 0.70)$. Out of the different modes of intervention delivery i.e., intravenous, subcutaneous and nerve block, maximum beneficial effect in reducing the incidence of PHN was noted in nerve block (RR 0.55; 95\% Cl, 0.34, 0.89).

Conclusions: The meta-analysis provides some evidence to support the use of combined local anaesthetic and steroids in reducing risk of post-herpetic neuralgia and duration of neuralgic pain in patients with herpes zoster rash.
\end{abstract}

KEYWORDS: Post-herpetic neuralgia, Herpes zoster rash, Anesthesia, Steroid, Management, Biological mechanism.

doi: https://doi.org/10.12669/pjms.38.3.5140

How to cite this:

Zhang X, Wang Z, Xian Y. Efficacy of local anaesthetic and steroid combination in prevention of post-herpetic neuralgia: A metaanalysis. Pak J Med Sci. 2022;38(3):757-765. doi: https://doi.org/10.12669/pjms.38.3.5140

This is an Open Access article distributed under the terms of the Creative Commons Attribution License (http://creativecommons.org/licenses/by/3.0), which permits unrestricted use, distribution, and reproduction in any medium, provided the original work is properly cited.

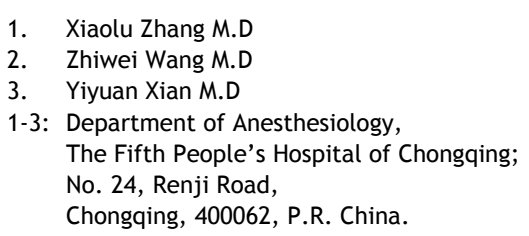

Note: Xiaolu Zhang and Zhiwei Wang are co-first authors and contributed equally to this work.

Correspondences:

Yiyuan Xian,

Department of Anesthesiology,

The Fifth People's Hospital of Chongqing;

No. 24, Renji Road, Chongqing,

400062, P.R. China.

Email: yiyuanxian_dr@163.com

* Received for Publication:

* Revision Received:

* Final Revision Accepted:
July 6, 2021

August 9, 2021

September 30, 2021

\section{INTRODUCTION}

Reactivation of the varicella zoster virus in the dorsal root ganglion, post the primary infection, leads to Herpes Zoster. ${ }^{1}$ The condition is primarily encountered when the cellular immunity is compromised. Usual clinical presentation in the acute phase is of dermatomal vesicular rash, which is unilateral. ${ }^{1,2}$ One of the common debilitating complications is the Post-herpetic neuralgia (PHN) and is clinically considered to be present when, after the onset of rash, the Herpes Zoster associated pain continues for more than 90 days. ${ }^{3,4}$ Epidemiological data indicates that the incidence of PNH varies from $5 \%$ to more than 30\% depending upon the operational definitions used, characteristics of the population studies and the 
study methodology adopted..$^{2-4}$ Further, studies suggest that the intensity of the pain is influenced by age as well as presence of other risk factors such as prodromal pain, severity of pain during acute episode, severity of rash, immunological state and presence or absence of diabetes. ${ }^{3,4}$

It is important to understand the key biological mechanism that leads to PHN so that effective treatment strategies could be developed. Herpes zoster is often associated with inflammation of the dorsal root ganglion and the associated peripheral nerves and this inflammation is widely implicated as the causative factor for PHN. ${ }^{4,5}$ Therefore, it would be logical to consider treatment strategies that aim to reduce inflammation and thereby, alleviate pain. Existing studies have evaluated the role of local anaesthetics and steroids in the treatment and management of PHN. In a metaanalysis by Kim et al published in 2017, efficacy of nerve block using local anaesthetics and/or steroid injections have been reviewed. ${ }^{6}$ The authors found that the incidence of $\mathrm{PHN}$ in the group receiving nerve block reduced by $57 \%$, in comparison to the standard of care group. Also, application of nerve block reduced the duration of zoster related pain. While this review is informative, there is a need to update this review as new trials have been published and their inclusion in the meta-analysis will be pertinent.

The purpose of this meta-analysis is to provide the most updated estimates on the efficacy of local anaesthetics and steroid injections for preventing and managing PHN, compared to the standard treatment using anti-viral and analgesic medications. The primary objective was to evaluate incidence of post-herpetic neuralgia at three months from start of rash and the alteration in the duration of pain with use of a combination of local anaesthetics and corticosteroids injections against standard medical treatment or placebo. We considered the incidence of PHN at 3 months from start of rash as PHN is clinically considered to be present when, after the onset of rash, the Herpes Zoster associated pain continues for more than 90 days.

\section{METHODS}

A comprehensive search was done systematically through PubMed, Scopus, CENTRAL (Cochrane Central Register of Controlled Trials) and Google scholar databases for papers published until $15^{\text {th }}$ July, 2021. Free text words and medical subject heading $(\mathrm{MeSH})$ terms were used. The key aim was to identify randomized controlled trials that evaluated the effect of local anaesthetics and steroid injections for preventing and managing PHN, compared to the standard treatment using anti-viral and analgesic medications on incidence of post-herpetic neuralgia and duration of pain. Studies that reported relevant outcome measures of interest to this meta-analysis were potentially considered for inclusion.

Two authors reviewed citations and selected studies. After removing the duplicates, screening of titles and abstracts was performed as a first step. Thereafter, review of the full text of potential studies was done. Any discrepancies related to the inclusion of studies were resolved through detailed discussion among the study authors. Only those studies were selected for the meta-analysis that adequately suited the inclusion criteria. The bibliographic list of the identified studies and relevant reviews on the subject were examined for additional possible studies.

Inclusion Criteria: For a study to be included in the meta-analysis, it should have been a randomized controlled trial or a quasi-experimental trial conducted among subjects experiencing Herpes Zoster within 14 days after onset of the rash. The study should have compared the efficacy of local anaesthetics and steroid injections for preventing and managing $\mathrm{PHN}$, compared to the standard treatment using anti-viral and analgesic medications/placebo.

Exclusion Criteria: Non-randomized studies such as case-reports, observational studies (case-control, cohort studies) or review articles were excluded. Also, those studies that did not compare a "combination" of local anaesthetic and corticosteroid injections against "standard care/ placebo" were excluded.

Extraction of relevant data from included studies was done by two authors independently, using a data extraction sheet. Following data from eligible studies were extracted: surname of first author, year in which the study was published, geographical location where the study was done, design of the study, characteristics of the study subjects, study groups and key findings of the study. The methodological assessment was done independently by two authors using the assessment tool by Cochrane. ${ }^{7}$

Statistical Analysis: Statistical analysis was done using STATA version 13.0. Effect sizes were reported as weighted mean differences (WMD) for continuous outcomes. For categorical outcomes, pooled relative risks were reported. All estimates 
were reported with $95 \%$ confidence intervals (CI). Subgroup analysis was done based on the mode of administration of the local anaesthetic and steroids i.e., intravenous, subcutaneous or nerve block. Nerve block meant injecting the local anaesthetic and steroid in a localized area to block spinal nerves and included epidural, paravertebral and stellate ganglion block. Heterogeneity of effects was assessed and quantified by the $\mathrm{I}^{2}$. $\mathrm{I}^{2}$ value $>50 \%$ was considered to represent substantial heterogeneity. ${ }^{8}$ In cases with substantial heterogeneity, random effects model was used. ${ }^{8}$ A p-value of $<0.05$ was considered statistically significant. Publication bias was assessed using Egger's test and visually inspected using funnel plots. Quality of the evidence generated was assessed using GRADE criteria and categorized as "High", "Moderate", "Low" or "Very low".

\section{RESULTS}

A total of 417 unique citations were obtained upon executing the search strategy in the PubMed, Scopus, CENTRAL (Cochrane Central Register of Controlled Trials) and Google scholar databases (Fig.1). Out of these, 305 were excluded based on title screening. Further, 93 citations were excluded after reading of the abstract. Full text of the remaining 19 articles were reviewed. Out of these, nine articles were excluded upon full text review. The final number of included articles in this metaanalysis was $10 .{ }^{10-19}$ Supplementary Table-I presents

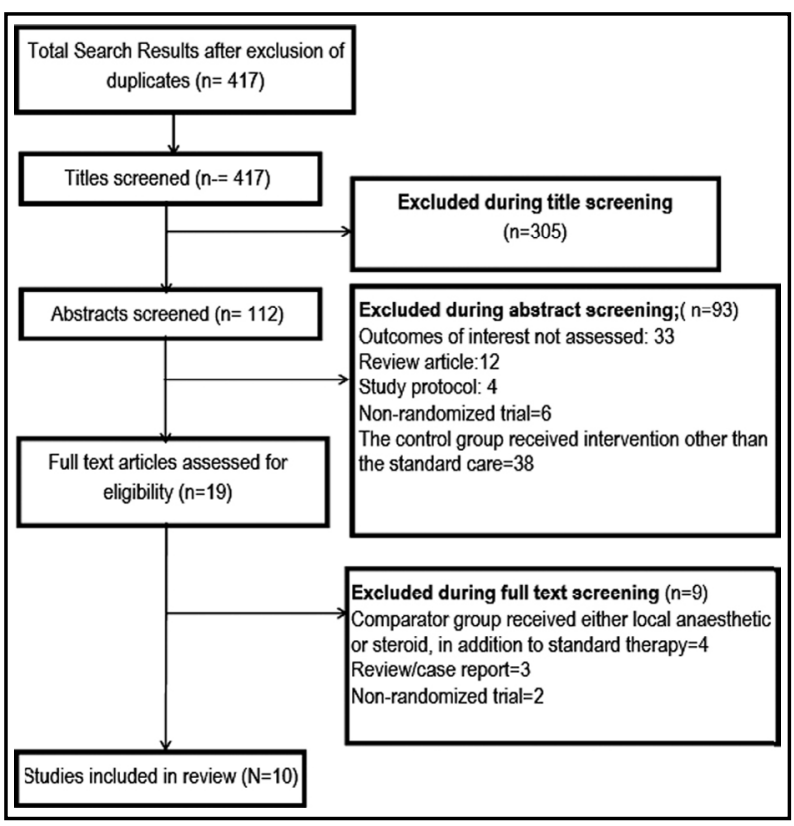

Fig.1: Selection process of the studies included in the review.

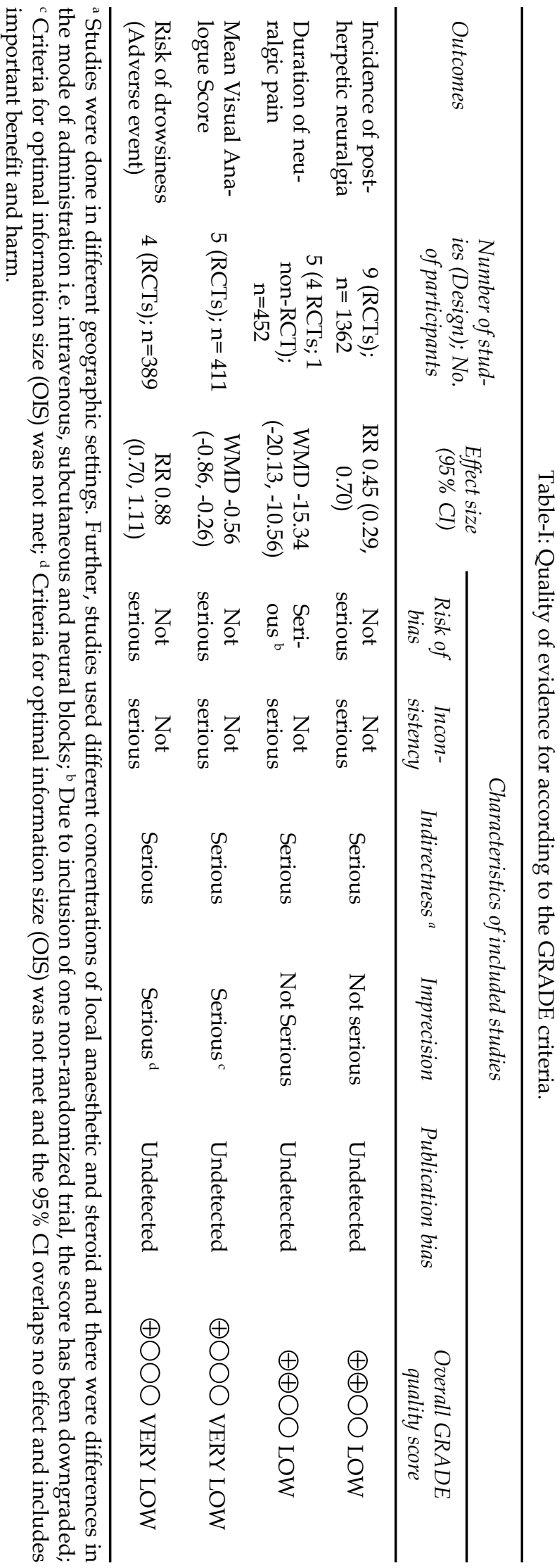

Pak J Med Sci March-April 2022 Vol. 38 No. $3 \quad$ www.pjms.org.pk 


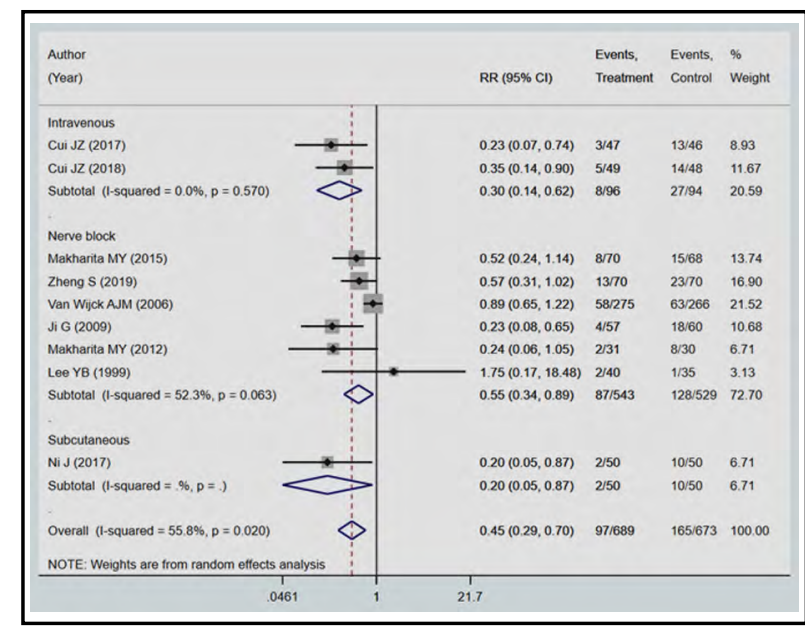

Fig.2: Pooled effect of local anaesthetics and steroid injections on incidence of post-herpetic neuralgia at 3 months from onset of rash.

the key characteristics of the included studies along with the key findings. All the included studies were randomized clinical trials, except one, which was a prospective non-randomized comparative clinical trial ${ }^{17}$. Five studies were done in China, two studies each in Egypt and South Korea and one study in Netherlands. All the studies, except one, adopted random sequence generation; allocation concealment, blinding of participants and blinding of study personnel was adequately reported in eight out of 10 studies; in nine studies, blinding of the outcome assessment team was reported to be done. Overall, the included studies had good quality.

The analysis based on the route of administration showed that the maximum beneficial effect was noted in nerve block (RR 0.55; 95\% CI, 0.34, 0.89; $\left.\mathrm{I}^{2}=52.3 \%\right)$ followed by intravenous route (RR $0.30 ; 95 \% \mathrm{CI}, 0.14,0.62 ; \mathrm{I}^{2}=0.0 \%$ ) (Fig.2). Only one study reported evidence on subcutaneous route and the effect size was significant, although with wide confidence intervals (RR 0.20; 95\% CI, 0.05, $0.87)$.

Additionally, the pooled risk ratios (RR) suggest a significant beneficial effect of a combination of local anaesthetic and steroid injection in reducing the incidence of post-herpetic neuralgia, compared to standard care/placebo. Compared to standard care/placebo, those receiving a combination of local anaesthetic and steroid injection had 55\% lower risk of PHN at three months from onset of rash (RR 0.45; 95\% CI, 0.29; 0.70; $\mathrm{I}^{2}=55.8 \%$ ) (Fig.2). There was no evidence of publication bias (P-value $=0.089)$.

The maximum reduction in the duration of pain (in days) was noted in subjects that received the

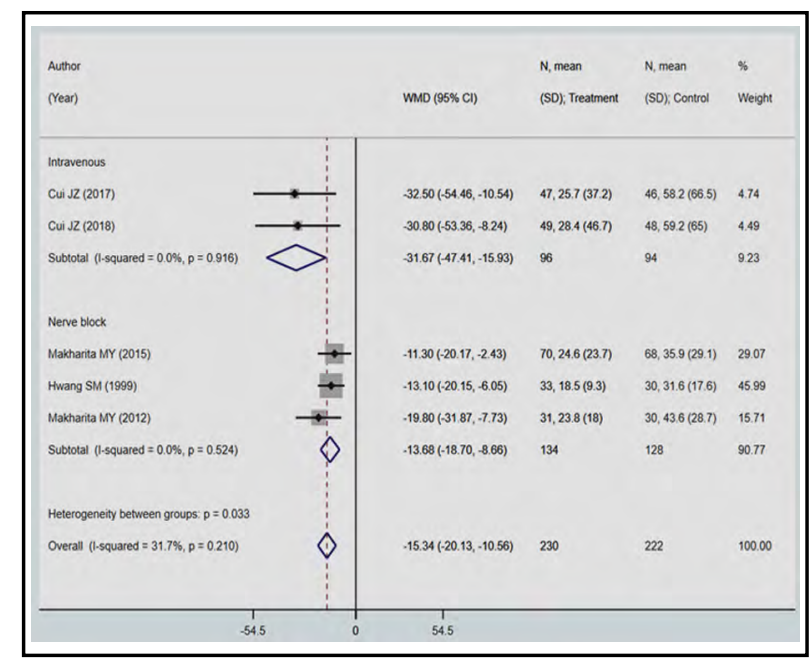

Fig.3: Pooled effect of local anaesthetic and steroid injection on duration of neuralgic pain (in days).

intervention intravenously (WMD -31.67; 95\%CI, $\left.-47.41,-15.93 ; \mathrm{I}^{2}=0.0 \%\right)$ followed by nerve block (WMD -13.68; 95\%CI, -18.70, -8.66; $\mathrm{I}^{2}=0.0 \%$ ) (Fig.3). There were no studies on subcutaneous mode of delivery of local anaesthetic and steroid that reported this outcome.

From the overall pooling of the studies, irrespective of the mode of delivery of the intervention, there were significant differences in the duration of neuralgic pain (in days) between subjects receiving a combination of local anaesthetic and steroid injection and those that received standard care/placebo. The overall mean difference (in days) between the two groups was statistically significant (WMD -15.34; 95\%CI, -20.13, -10.56 ; $\mathrm{I}^{2}=31.7 \%$ ) (Fig.3). Among those receiving the intervention, the mean duration of pain was around 15 days lesser than those that received standard care/placebo. There was no evidence of publication bias ( $\mathrm{P}$-value $=0.153$ ).

Among those receiving local anaesthetic and steroid through intravenous route, the intensity of neuralgic pain was significantly lesser compared to those that received standard care/placebo (WMD $-0.89 ; 95 \%$ CI $-1.51,-0.28 ; \mathrm{I}^{2}=0.0 \%$ ) (Supplementary Fig.1). In those receiving nerve block, there was also a significant reduction in the intensity of pain, although lesser than intravenous route ((WMD $\left.-0.46 ; 95 \% \mathrm{CI},-0.80,-0.12 ; \mathrm{I}^{2}=36.1 \%\right)$. There were no studies on subcutaneous mode of delivery of local anaesthetic and steroid that reported this outcome.

In the overall pooled analyses, among those receiving the intervention, the intensity of neuralgic pain was lesser than those that received 


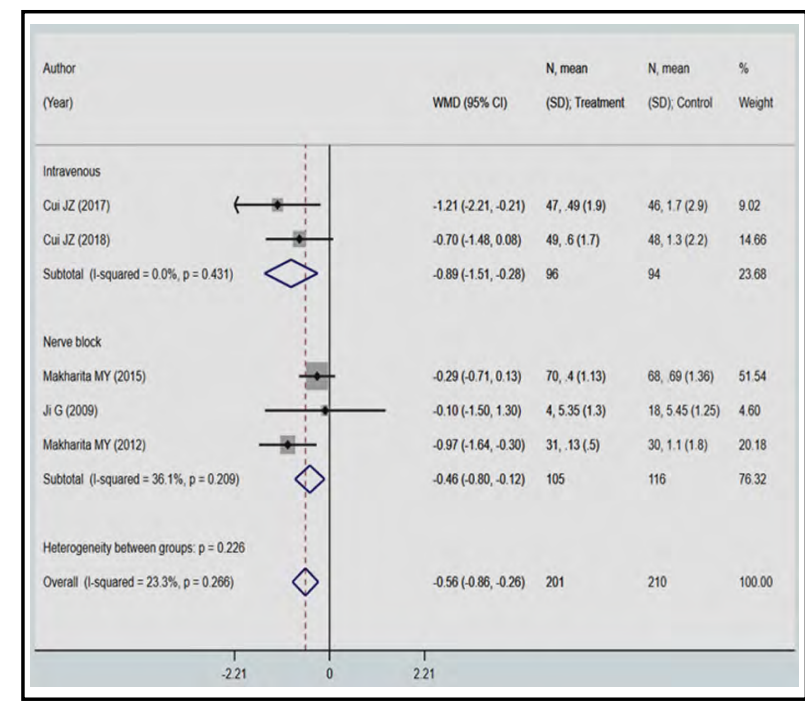

Supplementary Fig.1: Pooled effect of local anaesthetic and steroid injection on mean scores on Visual Analogue Scale.

standard care/placebo at 3 months from the onset of rash. The mean difference between the two groups was statistically significant (WMD -0.56; 95\% CI, -0.86, -0.26; $\mathrm{I}^{2}=23.3 \%$ ) (Supplementary Fig.1). There was no evidence of publication bias $(P$-value $=0.438)$.

Adverse events: The included studies did not report an increased incidence of adverse events in those receiving a combination of local anaesthetic and steroid injection, compared to those receiving standard care/placebo. The intervention was not associated with an increased risk of drowsiness (RR $0.88,95 \% \mathrm{CI} ; 0.70 ; 1.11 ; \mathrm{I}^{2}=0.0 \%$ ) (Supplementary Fig.2). Even with regards to the mode of administration i.e., intravenous (RR 0.94, 95\% CI; $0.61 ; 1.44 ; \mathrm{I}^{2}=0.0 \%$ ) or nerve block (RR $0.85,95 \% \mathrm{CI}$; $\left.0.65 ; 1.12 ; \mathrm{I}^{2}=0.0 \%\right)$, there were no differential risk compared to the standard care (Supplementary Fig.2). There was no evidence of publication bias (P-value $=0.602$ ).

The evidence on risk of post-herpetic neuralgia and on the duration of neuralgic pain was assessed to be of "low quality" whereas for the visual analogue scores and risk of drowsiness (denoting adverse events), the quality was "very low" (Table-I).

\section{DISCUSSION}

Our current understanding of the PHN is that herpes zoster infection initiated an acute inflammatory state in the dorsal root ganglion which subsequently leads to increased sympathetic vasoconstriction and consequent neural

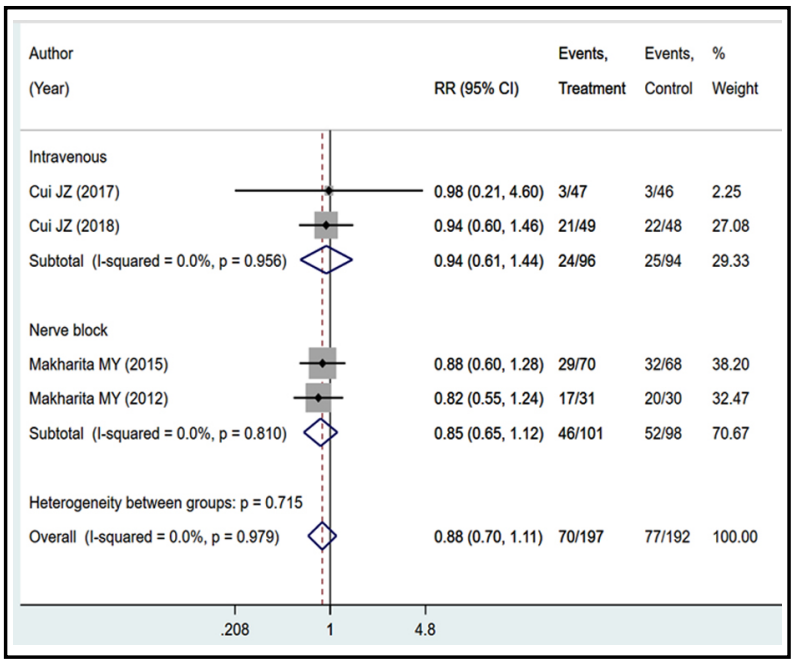

Supplementary Fig.2: Pooled risk of having drowsiness in those receiving local anaesthetic and steroid injection, compared to those receiving standard medical care and/or placebo.

damage. ${ }^{20,21}$ The beneficial effects of injecting local anaesthetic and steroids could be because of sympathetic blockage, thereby inhibiting vasoconstriction and due to anaesthetization of the dorsal root ganglion and posterior spinal nerve. ${ }^{20-22}$ Numerous pharmacotherapeutic agents have been used to treat or prevent PHN. These agents include antiviral medications, analgesics, corticosteroids and in some cases, antidepressants and anticonvulsants. ${ }^{23}$ While the use of antiviral medications has been shown to reduce the acute herpes zoster pain and accelerates healing of the lesions, it's benefits in prevention of PHN remain non-conclusive. ${ }^{23}$ Oral corticosteroid in combination with an antiviral therapy alleviates pain from herpes zoster (HZ) but minimal effect was noted in terms of reducing the severity and duration of the pain. ${ }^{23}$ Use of analgesics remains controversial as it can reduce pain but on the other hand, can also aggravate the lesions of HZ. ${ }^{23}$ Use of opioids is associated with side effects such as nausea, dizziness, somnolence, and in some case, constipation. ${ }^{23}$ The current evidence of the efficacy of using combined local anaesthetic and steroids in the prevention and management of PHN is promising but not well established. In this review, we aimed to synthesize all the available randomized controlled trials and present the most updated evidence.

The current meta-analysis was undertaken to provide an updated synthesized estimate of the efficacy of local anaesthetics in combination with 
Xiaolu Zhang et al.

Supplementary Table-I: Key details of the studies included in the meta-analysis.

\begin{tabular}{|c|c|c|c|c|c|}
\hline $\begin{array}{l}\text { Author, year } \\
\text { of publication }\end{array}$ & Country & $\begin{array}{l}\text { Study } \\
\text { design }\end{array}$ & Subjects & $\begin{array}{l}\text { Intervention and } \\
\text { control groups }\end{array}$ & Key outcome \\
\hline Cui JZ (2017) & China & RCT & $\begin{array}{l}\text { Ages } 50-80 \\
\text { years old, } \\
\text { experiencing } \\
\text { Herpes Zoster } \\
\text { within } 7 \text { days } \\
\text { after onset of } \\
\text { the rash } \\
\text { and HZ pain } \\
\text { intensity } \geq 4 \text { on } \\
\text { the visual } \\
\text { analog scale } \\
\text { (VAS). }\end{array}$ & $\begin{array}{l}\text { Control: Antiviral } \\
\text { medication along with } \\
\text { analgesics } \\
\text { Intervention: Antiviral } \\
\text { medication along with } \\
\text { analgesics AND repeated } \\
\text { intracutaneous injections } \\
\text { of } 15 \mathrm{ml} \\
0.25 \% \text { ropivacaine and } \\
40 \mathrm{mg} \text { methylpredniso- } \\
\text { lone every } \\
48 \mathrm{~h} \text { for a week (total } 4 \\
\text { injections) }\end{array}$ & $\begin{array}{l}\text { Incidence of Post-herpetic neuralgia } \\
\text { (PHN) at } 12 \text { weeks } \\
\text { Control: } 13 / 46 \text { (28.3\%); Intervention: } \\
\text { 3/47 (6.4\%) } \\
\text { Mean (SD) duration of pain (in days) } \\
\text { Control: } 58.2 \text { (66.5); Intervention: } 25.7 \\
\text { (37.2) } \\
\text { Mean (SD) VAS score at } 12 \text { weeks } \\
\text { Control: } 1.7 \text { (2.9); Intervention: } 0.49 \\
\text { (1.9) } \\
\text { Adverse effects } \\
\text { Nausea/vomiting } \\
\text { Control: } 4 / 46(8.7 \%) \text {; Intervention: } \\
\text { 5/47 (8.5\%) } \\
\text { Drowsiness } \\
\text { Control: } 3 / 46(6.5 \%) ; \text { Intervention: } \\
3 / 47 \text { (6.1\%) }\end{array}$ \\
\hline Cui JZ (2018) & China & RCT & $\begin{array}{l}\text { Ages } 50-80 \\
\text { years old, } \\
\text { experiencing } \\
\text { Herpes Zoster } \\
\text { within } 7 \text { days } \\
\text { after onset of } \\
\text { the rash } \\
\text { and HZ pain } \\
\text { intensity } \geq 4 \text { on } \\
\text { the visual } \\
\text { analog scale } \\
\text { (VAS). }\end{array}$ & $\begin{array}{l}\text { All patients received } \\
\text { standard treatment ( } 800 \\
\text { mg acyclovir } 5 \text { times } \\
\text { daily and } 150 \mathrm{mg} \text { prega- } \\
\text { balin twice } \\
\text { daily for } 7 \text { days) } \\
\text { Intervention: Intra- } \\
\text { cutaneous injection of } 15 \\
\mathrm{~mL} \text { of } 40 \mathrm{mg} \text { methylpred- } \\
\text { nisolone } \\
\text { plus } 14 \mathrm{~mL} \text { of } 0.25 \% \\
\text { ropivacaine } \\
\text { Control: intra-cutaneous } \\
\text { injection of } 15 \mathrm{~mL}\end{array}$ & $\begin{array}{l}\text { Incidence of Post-herpetic neuralgia } \\
\text { (PHN) at } 12 \text { weeks } \\
\text { Control: } 14 / 48 \text { (29.2\%); Intervention: } \\
5 / 49(10.2 \%) \\
\text { Mean (SD) duration of pain (in days) } \\
\text { Control: } 59.2 \text { (65.0); Intervention: } 28.4 \\
\text { (46.7) } \\
\text { Mean (SD) VAS score at } 12 \text { weeks } \\
\text { Control: } 1.3(2.2) \text {; Intervention: } 0.6 \\
\text { (1.7) } \\
\text { Adverse effects } \\
\text { Drowsiness in the first week of treat- } \\
\text { ment } \\
\text { Control: } 22 / 48 \text { (45.8\%); Intervention: } \\
21 / 49(42.6 \%)\end{array}$ \\
\hline $\begin{array}{l}\text { Makharita MY } \\
\text { et al }(2015)^{12}\end{array}$ & Egypt & RCT & $\begin{array}{l}\text { Patients over } \\
50 \text { years who } \\
\text { had chest wall } \\
\text { herpetic erup- } \\
\text { tion of less } \\
\text { than } 1 \text { week } \\
\text { with moder- } \\
\text { ate and severe } \\
\text { pain }\end{array}$ & $\begin{array}{l}\text { All patients received } \\
\text { pregabalin in a dose of } \\
150 \mathrm{mg} \text { twice daily. } \\
\text { Control: Nerve block } \\
\text { using } 10 \mathrm{~mL} \text { saline as pla- } \\
\text { cebo under fluoroscopy } \\
\text { Intervention: Nerve block } \\
\text { with } 25 \mathrm{mg} \text { bupiv- } \\
\text { acaine } 0.5 \% \text {, plus } 8 \mathrm{mg} \\
\text { dexamethasone in a total } \\
\text { volume of } 10 \mathrm{~mL} \text { under } \\
\text { fluoroscopy }\end{array}$ & $\begin{array}{l}\text { Incidence of Post-herpetic neuralgia } \\
\text { (PHN) at } 12 \text { weeks } \\
\text { Control: } 15 / 68 \text { (22.1\%); Intervention: } \\
8 / 70 \text { (11.4\%) } \\
\text { Mean (SD) duration of pain (in days) } \\
\text { Control: } 35.9 \text { (29.1); Intervention: } 24.6 \\
\text { (23.7) } \\
\text { Mean (SD) VAS score at } 12 \text { weeks } \\
\text { Control: } 0.69 \text { (1.36); Intervention: } 0.40 \\
\text { (1.13) } \\
\text { Adverse effects } \\
\text { Drowsiness in the first week of treat- } \\
\text { ment } \\
\text { Control: } 32 / 68 \text { (47.1\%); Intervention: } \\
29 / 70(41.4 \%)\end{array}$ \\
\hline $\begin{array}{l}\text { Ni J et al } \\
(2017)^{13}\end{array}$ & China & $\mathrm{RCT}$ & $\begin{array}{l}\text { Age } \geq 50 \\
\text { years; Herpes } \\
\text { Zoster infec- } \\
\text { tion (with rash } \\
\text { duration }<7 \\
\text { days) and } \\
\text { pain numeri- } \\
\text { cal rating scale } \\
\text { (NRS) score } \\
>3\end{array}$ & $\begin{array}{l}\text { All patients received } \\
\text { standard treatment i.e. } \\
\text { analgesics (as needed) } \\
\text { and antiviral medication } \\
\text { (oral } \\
\text { acyclovir } 800 \mathrm{mg} 5 \text { times } \\
\text { daily) } \\
\text { Intervention: In addition } \\
\text { to the standard treatment } \\
\text { received a combination of } \\
\text { triamcinolone }(10 \mathrm{mg}) \\
\text { and lidocaine }(0.5 \%), \\
\text { injected subcutaneously }\end{array}$ & $\begin{array}{l}\text { Incidence of Post-herpetic neuralgia } \\
\text { (PHN) at } 12 \text { weeks } \\
\text { Control: } 10 / 50(20.0 \%) \text {; Intervention: } \\
2 / 50(4.0 \%) \\
\text { No serious adverse events were noted } \\
\text { in any of the two groups }\end{array}$ \\
\hline
\end{tabular}




\begin{tabular}{|c|c|c|c|c|c|}
\hline Zheng S et al & China & RCT & $\begin{array}{l}\text { Those aged } \\
50 \text { years or } \\
\text { more with } \\
\text { a confirmed } \\
\text { diagnosis of } \\
\text { cervical } \\
\text { Herpes Zoster } \\
\text { with unilateral } \\
\text { lesions appear- }\end{array}$ & $\begin{array}{l}\text { Control: received the } \\
\text { standard antiviral treat- } \\
\text { ment (famciclovir } \\
250 \mathrm{mg} 3 \text { times daily for } \\
7 \text { days) plus ultrasound- } \\
\text { guided CRB with similar- } \\
\text { looking placebo. } \\
\text { Intervention: received } \\
\text { standard antiviral treat- }\end{array}$ & $\begin{array}{l}\text { Incidence of Post-herpetic neuralgia } \\
\text { (PHN) at } 12 \text { weeks } \\
\text { Control: } 23 / 70(32.9 \%) \text {; Intervention: } \\
13 / 70(18.6 \%)\end{array}$ \\
\hline & & & $\begin{array}{l}\text { ing between } \\
\text { level C5 and } \\
\text { level C7; rash } \\
\text { present within } \\
3 \text { days; zoster } \\
\text { associated } \\
\text { pain }\end{array}$ & $\begin{array}{l}\text { ment plus ultrasound } \\
\text { guided cervical nerve } \\
\text { root block }(\mathrm{CRB}) \text { with } \\
\text { mixed drug liquid } \\
\text { (lidocaine } 4 \mathrm{mg} / \mathrm{mL}+ \\
\text { triamcinolone } 1 \mathrm{mg} / \mathrm{mL} \\
+ \text { cobamamide } 0.5 \mathrm{mg} / \\
\mathrm{mL}+\text { normal saline). }\end{array}$ & $\begin{array}{l}\text { No serious adverse events were noted } \\
\text { in any of the two groups }\end{array}$ \\
\hline $\begin{array}{l}\text { Van Wijck } \\
\text { AJM et al }\end{array}$ & $\begin{array}{l}\text { Nether- } \\
\text { lands }\end{array}$ & RCT & $\begin{array}{l}\text { Herpes zoster } \\
\text { within } 7 \text { days } \\
\text { after onset of } \\
\text { the rash, } \\
\text { dermatome }\end{array}$ & $\begin{array}{l}\text { Control: Patients ran- } \\
\text { domised to the control } \\
\text { group received the cur- } \\
\text { rent standard treatment } \\
\text { for herpes, consisting of } \\
\text { analgesics as needed and } \\
\text { antiviral edication } \\
\text { Intervention: Patients al- } \\
\text { located to the nerve block } \\
\text { group also received the }\end{array}$ & $\begin{array}{l}\text { Incidence of Post-herpetic neuralgia } \\
\text { (PHN) at } 12 \text { weeks } \\
\text { Control: } 63 / 266(24.0 \%) \text {; Intervention: } \\
58 / 275(21.0 \%)\end{array}$ \\
\hline & & & $\begin{array}{l}\text { below } \mathrm{C6} \text {, age } \\
\text { older than } 50 \\
\text { years }\end{array}$ & $\begin{array}{l}\text { standard treatment. } \\
\text { Additionally, they } \\
\text { received a mixture of } \\
80 \text { mg methylpredni- } \\
\text { solone acetate and } 10 \\
\text { mg bupivacaine }(0 \cdot 25 \% \\
\text { weight/volume) injected } \\
\text { epidurally. }\end{array}$ & $\begin{array}{l}\text { No serious adverse events were noted } \\
\text { in any of the two groups }\end{array}$ \\
\hline $\begin{array}{l}\text { Ji G et al } \\
(2009)^{16}\end{array}$ & China & $\mathrm{RCT}$ & $\begin{array}{l}\text { Herpes zoster } \\
\text { within } 7 \text { days } \\
\text { after onset of } \\
\text { the rash, der- } \\
\text { matome below } \\
\text { C6, age older } \\
\text { than } 50 \text { yrs. }\end{array}$ & $\begin{array}{l}\text { Control: Patients rand- } \\
\text { omized to the control } \\
\text { group received the } \\
\text { current standard treat- } \\
\text { ment for herpes (oral } \\
\text { administration of } 800 \mathrm{mg} \\
\text { acyclovir, } 5 \text { times daily } \\
\text { for } 7 \text { days, and analgesics } \\
\text { as needed). } \\
\text { Intervention: Patients } \\
\text { allocated to this group } \\
\text { also received standard } \\
\text { treatment. Additionally, } \\
\text { they were given repeti- } \\
\text { tive nerve block with a } \\
\text { mixture of } 10 \text { mL } 0.25 \% \\
\text { bupivacaine and } 40 \mathrm{mg} \\
\text { methylprednisolone } \\
\text { acetate every } 48 \mathrm{~h} \text { for a } \\
\text { week (total } 4 \text { injections at } \\
\text { each desired level) }\end{array}$ & $\begin{array}{l}\text { Incidence of Post-herpetic neuralgia } \\
\text { (PHN) at } 12 \text { weeks } \\
\text { Control: } 18 / 60(30.0 \%) \text {; Intervention: } \\
4 / 57(7.0 \%) \\
\text { Mean (SD) Visual Analogue Scale } \\
\text { (VAS) score at } 12 \text { weeks } \\
\text { Control (N=18): } 5.45(1.25) \text {; Interven- } \\
\text { tion (N=4): } 5.35(1.30)\end{array}$ \\
\hline $\begin{array}{l}\text { Hwang SM et } \\
\text { al }(1999)^{17}\end{array}$ & $\begin{array}{l}\text { South } \\
\text { Korea }\end{array}$ & $\begin{array}{l}\text { Prospec- } \\
\text { tive } \\
\text { non-ran- } \\
\text { domized } \\
\text { compara- } \\
\text { tive clini- } \\
\text { cal trial }\end{array}$ & $\begin{array}{l}\text { Patients with } \\
\text { Herpes Zoster } \\
\text { within } 14 \text { days } \\
\text { of onset of } \\
\text { disease; Mean } \\
\text { age of around } \\
60 \text { years }\end{array}$ & $\begin{array}{l}\text { Control: Intravenous } \\
\text { acyclovir (5 mg/ kg three } \\
\text { times a day for } 7 \text { days) } \\
\text { Intervention: Intravenous } \\
\text { acyclovir with nerve } \\
\text { block (methylpredniso- } \\
\text { lone acetate and } 0.125 \% \\
\text { bupivacaine) for } 7 \text { days }\end{array}$ & $\begin{array}{l}\text { Mean (SD) duration of pain (in days) } \\
\text { Control: } 31.6 \text { (17.6); Intervention: } 18.5 \\
(9.3) \\
\text { No serious adverse events were noted } \\
\text { in any of the two groups }\end{array}$ \\
\hline
\end{tabular}




\begin{tabular}{|c|c|c|c|c|c|}
\hline $\begin{array}{l}\text { Makharita MY } \\
\text { et al }(2012)^{18}\end{array}$ & Egypt & $\mathrm{RCT}$ & $\begin{array}{l}\text { Adult patients } \\
\text { aged over } 50 \\
\text { years with her- } \\
\text { petic eruption } \\
\text { of less than } 2 \\
\text { weeks and un- } \\
\text { der or received } \\
\text { appropri- } \\
\text { ate antiviral } \\
\text { therapy }\end{array}$ & $\begin{array}{l}\text { Control: stellate ganglion } \\
\text { block using } 8 \mathrm{~mL} \text { saline } \\
\text { as placebo } \\
\text { Intervention: stellate gan- } \\
\text { glion block using } 6 \mathrm{~mL} \\
\text { bupivacaine } 0.125 \% \text { plus } \\
8 \mathrm{mg} \text { dexamethasone in a } \\
\text { total volume of } 8 \mathrm{~mL}\end{array}$ & $\begin{array}{l}\text { Incidence of Post-herpetic neuralgia } \\
\text { (PHN) at } 12 \text { weeks } \\
\text { Control: } 8 / 30 \text { (26.7\%); Intervention: } \\
2 / 31 \text { (6.5\%) } \\
\text { Mean (SD) duration of pain (in days) } \\
\text { Control: } 43.6 \text { (28.7); Intervention: } 23.8 \\
\text { (18.0) } \\
\text { Mean (SD) VAS score at } 12 \text { weeks } \\
\text { Control: } 1.1 \text { (1.8); Intervention: } 0.13 \\
\text { (0.5) } \\
\text { Adverse effects } \\
\text { Drowsiness } \\
\text { Control: } 20 / 30(66.7 \%) \text {; Intervention: } \\
\text { 17/31 (54.8\%) }\end{array}$ \\
\hline $\begin{array}{l}\text { Lee YB et al } \\
(1999)^{19}\end{array}$ & $\begin{array}{l}\text { South } \\
\text { Korea }\end{array}$ & $\mathrm{RCT}$ & $\begin{array}{l}\text { HZ patients } \\
\text { located in } \\
\text { the cervi- } \\
\text { cal through } \\
\text { the sacral } \\
\text { dermatome } \\
\text { within } 20 \text { days } \\
\text { of onset of the } \\
\text { disease }\end{array}$ & $\begin{array}{l}\text { Control: Standard } \\
\text { therapy with antiviral } \\
\text { agents (acyclovir } 5 \mathrm{mg} / \\
\mathrm{kg} 3 \text { times a day for 5-7 } \\
\text { days) and supplementary } \\
\text { analgesics } \\
\text { Intervention: Standard } \\
\text { therapy plus repetitive } \\
\text { nerve block (bupivacaine } \\
\text { with methylpredniso- } \\
\text { lone) }\end{array}$ & $\begin{array}{l}\text { Incidence of Post-herpetic neuralgia } \\
\text { (PHN) at } 12 \text { weeks } \\
\text { Control: } 1 / 35(2.85 \%) \text {; Intervention: } \\
2 / 40(5.0 \%)\end{array}$ \\
\hline
\end{tabular}

injectable steroids in prevention and management of post-herpetic neuralgia and in reducing the duration of neuralgic pain, compared to the standard care and/or placebo. We found that use of a combination of local anaesthetic and injectable steroids reduced the risk of experiencing PHN by 55\% and the duration of pain. We further observed no significant increase in the adverse side effects with use of this combination. Our findings corroborate with the recently conducted review by Kim $\mathrm{HJ}$ et al. ${ }^{6}$ that showed that nerve block using local anaesthetics and/or steroid injections reduced the incidence of post-herpetic neuralgia by $57 \%$ and reduced the duration of zoster related pain, in comparison to the standard of care. We also noted that there were differential effects on incidence of PHN, duration of neuralgic pain and mean VAS score based on whether the intervention was delivered intravenously or through nerve block. Use of any of these modes should be governed by treating clinician's or the patient's preference as well as the skills of the clinician. The overall quality of evidence generated through the pooled analysis was "low to very low" and therefore, calls for more comprehensive and methodologically robust randomized controlled trials on this important clinical issue.

Limitations of the study: Firstly, for some of the studies, the sample size was small and could have affected the overall pooled estimates as well as limited the generalizability of the evidence. Secondly, the present meta-analysis cannot provide clear guidelines regarding frequency, duration, or type of local anesthetics and steroids to be used for the prevention and management of PHN.

\section{CONCLUSION}

The meta-analysis provides some evidence to support the use of combined local anaesthetic and steroids in reducing risk of post-herpetic neuralgia and duration of neuralgic pain in patients with herpes zoster rash. Further, the use of this combination is not associated with increase in adverse events. Overall, the GRADE assessments indicate that the current evidence is not of high quality and more robust and methodologically sound clinical trials on this aspect needs to be done.

\section{REFERENCES}

1. Gerada C, Campbell TM, Kennedy JJ, McSharry BP, Steain M, Slobedman B, Abendroth A. Manipulation of the Innate Immune Response by Varicella Zoster Virus. Front Immunol. 2020;24;11:1. doi: 10.3389/fimmu.2020.00001

2. Wareham DW, Breuer J. Herpes zoster. BMJ. 2007;334(7605):1211-1215. doi: $10.1136 /$ bmj.39206.571042.AE

3. Sampathkumar P, Drage LA, Martin DP. Herpes zoster (shingles) and postherpetic neuralgia. Mayo Clin Proc. 2009;84(3):274-280. doi: 10.1016/S0025-6196(11)61146-4

4. Kawai K, Gebremeskel BG, Acosta CJ. Systematic review of incidence and complications of herpes zoster: towards a global perspective. BMJ Open. 2014;4(6):e004833. doi: 10.1136/bmjopen-2014-004833 
5. Mallick-Searle T, Snodgrass B, Brant JM. Postherpetic neuralgia: epidemiology, pathophysiology, and pain management pharmacology. J Multidiscip Healthc. 2016;9:447-454. doi: 10.2147/JMDH.S106340

6. Kim HJ, Ahn HS, Lee JY, Choi SS, Cheong YS, Kwon K, et al. Effects of applying nerve blocks to prevent postherpetic neuralgia in patients with acute herpes zoster: a systematic review and meta-analysis. Korean J Pain. 2017;30(1):3-17. doi:10.3344/kjp.2017.30.1.3

7. Higgins JPT, Altman DG, Gøtzsche PC, Jüni P, Moher $\mathrm{D}$, Oxman $\mathrm{AD}$, et al. The Cochrane Collaboration's tool for assessing risk of bias in randomised trials. BMJ. 2011;343:d5928. doi: $10.1136 /$ bmj.d5928

8. Higgins JPT, Thomas J, Chandler J, Cumpston M, Li T, Page MJ, Welch VA (editors). Cochrane Handbook for Systematic Reviews of Interventions version 6.2 (updated February 2021). Cochrane, 2021. Available from www. training.cochrane.org/handbook

9. Atkins D, Best D, Briss PA, Eccles M, Falck-Ytter Y, Flottorp $S$, et al. Grading quality of evidence and strength of recommendations. BMJ. 2004;328(7454):1490. doi: 10.1136/ bmj.328.7454.1490

10. Cui J-Z, Zhang X-B, Zhu P, Zhao Z-B, Geng Z-S, Zhang Y-H, et al. Effect of Repetitive Intracutaneous Injections with Local Anesthetics and Steroids for Acute Thoracic Herpes Zoster and Incidence of Postherpetic Neuralgia. Pain Med. 2017;18(8):1566-1572. doi: $10.1093 / \mathrm{pm} / \mathrm{pnw} 190$

11. Cui JZ, Zhang JW, Yan F, Yang XN, Wang XL, Zhao ZB, et al. Effect of Single Intra-cutaneous Injection for Acute Thoracic Herpes Zoster and Incidence of Postherpetic Neuralgia. Pain Manag Nurs. 2018;19(2):186-194. doi: 10.1016/j.pmn.2017.09.002

12. Makharita MY, Amr YM, El-Bayoumy Y. Single paravertebral injection for acute thoracic herpes zoster: a randomized controlled trial. Pain Pract. 2015;15(3):229-235. doi: 10.1111/papr.12179

13. Ni J, Wang X, Tang Y, Yang L, Zeng Y, Guo Y. Subcutaneous Injection of Triamcinolone and Lidocaine to Prevent Postherpetic Neuralgia. Pain Physician. 2017;20(5):397-403.

14. Zheng S, Li X, Yang X, He L, Xue Y, Yang Z. UltrasoundGuided Cervical Nerve Root Block for the Treatment of Acute Cervical Herpes Zoster: A Randomized Controlled Clinical Study. Pain Pract. 2019;19(5):500-509. doi:10.1111/ papr.12770

15. van Wijck AJM, Opstelten W, Moons KGM, Essen GAV, Stolker RJ, Kalkman CJ, et al. The PINE study of epidural steroids and local anaesthetics to prevent postherpetic neuralgia: a randomised controlled trial. Lancet. 2006;367(9506):219-224. doi:10.1016/S0140 6736(06)68032-X
16. Ji G, Niu J, Shi Y, Hou L, Lu Y, Xiong L. The effectiveness of repetitive paravertebral injections with local anesthetics and steroids for the prevention of postherpetic neuralgia in patients with acute herpes zoster. Anesth Analg. 2009;109(5):1651-1655. doi: 10.1213/ ANE.0b013e3181b79075

17. Hwang SM, Kang YC, Lee YB, Yoon KB, Ahn SK, Choi $\mathrm{EH}$. The effects of epidural blockade on the acute pain in herpes zoster. Arch Dermatol. 1999;135(11):1359-1364. doi: 10.1001/archderm.135.11.1359

18. Makharita MY, Amr YM, El-Bayoumy Y. Effect of early stellate ganglion blockade for facial pain from acute herpes zoster and incidence of postherpetic neuralgia. Pain Physician. 2012;15(6):467-474.

19. Lee YB, Park JT, Han JW, Yoon KB. The Efficacy of Epidural Blockade on Acute Herpes Zoster. Korean J Pain. 1999;12(2):183-187.

20. Truini A, Galeotti F, Haanpaa M, Zucchi R, Albanesi A, Biasiotta A, et al. Pathophysiology of pain in postherpetic neuralgia: a clinical and neurophysiological study. Pain. 2008;140(3):405-410. doi: 10.1016/j.pain.2008.08.018

21. Thyregod HG, Rowbotham MC, Peters M, Possehn J, Berro M, Petersen KL. Natural history of pain following herpes zoster. Pain. 2007;128(1-2):148-156. doi:1 0.1016/j. pain.2006.09.021

22. Schutzer-Weissmann J, Farquhar-Smith P. Post-herpetic neuralgia - a review of current management and future directions. Expert Opin Pharmacother. 2017;18(16):1739-1750. doi: 10.1080/14656566.2017.1392508

23. Shrestha M, Chen A. Modalities in managing postherpetic neuralgia. Korean J Pain. 2018;31(4):235-243. doi: 10.3344/ kjp.2018.31.4.235

\section{Authors' Contributions:}

XZ: Conceived and designed the study.

ZW and YX: Collected the data and performed the analysis.

XZ: Involved in the Writing of the manuscript and is responsible for integrity of the study.

YX: Edited the manuscript.

All authors have read and approved the final manuscript. 